\title{
Correction to: Highway to (Digital) Surveillance: When Are Clients Coerced to Share Their Data with Insurers?
}

\author{
Michele Loi ${ }^{1,3} \cdot$ Christian Hauser $^{2} \cdot$ Markus Christen $^{1,3}$
}

Published online: 8 December 2020

(c) The Author(s) 2020

\section{Correction to: Journal of Business Ethics https://doi.org/10.1007/s10551-020-04668-1}

The initial online publication contained a typesetting mistake in the author information. The original article has been corrected.

Open Access This article is licensed under a Creative Commons Attribution 4.0 International License, which permits use, sharing, adaptation, distribution and reproduction in any medium or format, as long as you give appropriate credit to the original author(s) and the source, provide a link to the Creative Commons licence, and indicate if changes were made. The images or other third party material in this article are included in the article's Creative Commons licence, unless indicated otherwise in a credit line to the material. If material is not included in the article's Creative Commons licence and your intended use is not permitted by statutory regulation or exceeds the permitted use, you will need to obtain permission directly from the copyright holder. To view a copy of this licence, visit http://creativecommons.org/licenses/by/4.0/.

Publisher's Note Springer Nature remains neutral with regard to jurisdictional claims in published maps and institutional affiliations.

The original article can be found online at https://doi.org/10.1007/ s10551-020-04668-1.

Michele Loi

michele.loi@ibme.uzh.ch

Christian Hauser

Christian.Hauser@fhgr.ch

Markus Christen

christen@ethik.uzh.ch

1 Institute of Biomedical Ethics and the History of Medicine, University of Zurich, Zurich, Switzerland

2 PRME Business Integrity Action Center, University of Applied Sciences of the Grisons, Chur, Switzerland

3 Digital Society Initiative, University of Zurich, Zurich, Switzerland 